\title{
Forest Governance in Nepal: Rationale for Centralised Forest and Wildfire Management
}

\author{
Iván Győző Somlai \\ Email: Ivan.Somlai@INSEAD.edu \\ John Karakatsoulis \\ Wendy Gardner \\ Ambika P Gautam \\ Sundar Prasad Sharma \\ Bharat Adhikari
}

Numerous inter-related social and institutional factors are causing concern as to effective responses to the increasing number and severity of forest and wildfires in Nepal, due in similar measure to socio-cultural, politico-bureaucratic as well as global climatic issues. Our binational team of multisectoral field practitioners in bureaucratic as well as natural resource and fire management compiled and verified background information to more clearly discern the issues affecting improved fire governance and thereupon has made supportive recommendations for the belated establishment of a dedicated unit within the Government of Nepal Ministry of Forests and Soil Conservation to coordinate, administer and manage a comprehensive forest fire management programme.

Key words: Nepal, wildfire governance, bureaucratic restructuring

\section{Introduction}

Empirical and anecdotal insights (e.g. Sharma, 1996; UNISDR, 2007; USFS, 2014) over the past decades have been showing a tendency toward an increase in forest and wildfires in Nepal, while the effectiveness of response by the government and communities remains tempered by inadequate preparation and coordination (Onlinekhabar, 2016). It had already been progressively noted that 'increasing population density, prevailing economic problems, impose restrictions on efficient forest protection' (FAO, 1999) and that 'the Department of Forests (DoF) does not possess any special unit or team to deal with the problem of forest fire, 
including firefighting or management (MoFSC, 2015d). None of the 75 District Forest Offices, with a number of graduate foresters and forestry technicians, has either the capacity or capability for preventing or fighting forest fires' (Bajracharya, 2002). Establishing and maintaining fire lines in government forests has become increasingly rare (Magrath et al, 2013). This lack of capacities to organize sufficient fire response has resulted in reactive rather than proactive management.

Recent ravaging of 250,000 hectares of forest land-not counting settlements directly affected -is said to have been the worst in 15 years (Khadka, 2016); more proof is not needed that a strong central coordinating mechanism is timely. Responsible community forestry has interdependent aims to reduce environmental degradation, increased supply of timber and nontimber forest products while augmenting income and employment, making the management of fires inherently integral to maintaining a workable balance of environment and land management to sustain forest livelihoods and related initiatives.

A Canadian-Nepali research team investigated the bureaucratic, cultural and environmental impediments and thereafter proffered a vigorous support to the overdue development of practical steps for enhancing fire management.

\section{Methodology and process}

A literature review of government and consulting material reinforced by months of internet communication had already provided copious information as to common bottlenecks and recurrent issues outside of the control of well-meaning bureaucrats. A team member from the British Columbia Forest Service, who had previously been a senior officer within the Nepal Forest Service, contributed substantially to the team's contextual understanding.

In order to verify the team's perceptions, as well as to clarify the DoF's organization and administration relating to forest and wildfire management in rural areas, the team conducted a survey on Enquiry with the Department of Forests, Nepal - Forest Fire Control Management Focal Person. This study focused on the internal administration - an often neglected factor when assessing primarily field issues. Accordingly, the intent was that a detailed understanding of bureaucratic constraints and successes, discussed together with field realities, would yield a holistic overview and comprehensive understanding of fire management and related, realistic, essential improvements.

Supplementing this interview with a senior DoF staff were further clarifications from two workshops attended by government and non-government representatives of all levels (with $c .75$ participants), two rural community meetings (c.40), one national park orientation visit (c.15) and six private discussions with senior government officials. Moreover, a separate educational session was held with the Army's Shree Naya Shreenath Battalion responsible for conservation, including fire response, at Shivpuri Nagarjun National Park (c.20). 


\section{Results and discussion}

Results, corresponding with topics used in the questionnaire, are a composite of replies from the interview, amplified by later clarifications from discussions and field visits. Each of these topics represents an indispensible component of fire management bureaucracy within any government. The designated topics or functions are parts of an integrated whole; by better understanding each typical function, more reliable suggestions could be made.

\section{Management and organization}

The forest fire management function comes under the DoF (Annex 1), but without a separate section or unit to oversee forest fire management per se. There is only one designated Focal Person within the Forest Management Section line unit of the National Forest Division. There are detailed but rarely updated job descriptions within the DoF and no specifically described job description for the Focal Person except for designated title in the letter of appointment. Similarly, a Focal Person is designated for the Ministry itself. Currently, neither short-term Focal Person has an active role in forest fire management; rather, District Forest Officers (DFOs) lead the specific activities related to forest fire control, suppression and management at the field level, as part of the approved annual plan.

The general codes of conduct for civil servants, as articulated in the Civil Service Act (GoN, 1992) and as explained in the Forestry Act (GoN, 1993), require knowledge of and abiding by designated roles, conduct and responsibilities. Staff and community volunteers, however, might not similarly interpret the Department's values, as there is no tradition of orientating community volunteers about the government rules and regulations.

Despite forest fires being a big challenge in Nepal, adequate priority has not been extended to addressing related issues. There are insufficient staff and equipment, no training available on a scheduled basis, and no standard curriculum for use in any of the affected Districts. The UNISDR-Regional South Asia Wildland Fire Network Coordinator and the current Focal Person have been lobbying for establishing a dedicated, staffed and budgeted unit within the Ministry.

In the field, there are some limited funds and activities; however, without proper and regular training, officers cannot impart new knowledge and skills to communities. Of equal importance is to make provisions for fire control, suppression, management and training equipment at the district level.

\section{Planning, monitoring and evaluation}

No planning, monitoring or evaluation system for fire management exists at the Department or lower administrative levels. While the Focal Person might learn about fire incidents, resources are unavailable from the Department to allow coordination, control or mitigation; frequently, 
responses are handled only at the local level by the DFOs in coordination with local security forces and any locally available resources. Evaluations included are only those which are part of the annual performance reviews of DFOs with regard to the preventive measures introduced or implemented against forest fires, particularly in fire prone Districts. In many Districts, Community Forest User Group (CFUGs) are also involved in fire management programmes.

\section{Audit and financial management}

The annual budget ceiling is fixed by the Ministry of Finance: as an example, in the fiscal year 2015/2016 [2072/73]), only Rs. 7.3 million (c. USD 68,000) had been allocated, leaving an inadequate average of Rs. 97,335 (c. USD 910) per each of 75 Districts for fire management, albeit not every District receives funds. The Department then has to plan within this constrained ceiling. Budget ceilings are communicated to DFOs for planning. The centre does ask the Districts to include at least fire awareness, if funds be insufficient for other activities. Local plans are then usually communicated to (but not always discussed with) local stakeholders-often CFUGs with some responsibilities related to fires.

\section{Procurement}

Procurements are guided and governed by the Government of Nepal (GoN) Public Procurement Act (GoN Public, 2006) and the Public Procurement Regulations (GoN Public, 2007) which describe comprehensive processes for the procurement of any goods or services required by the Department, Division, Section or District Offices. However, there is no prepared list of necessary materials or equipment required for fire management at either central or District levels. Consequently, the use of makeshift tools and acceptance of sometimes incompatible foreign-donated tools, equipment and allied materials has become the norm.

\section{Subcontracting}

Subcontracting of services is allowed following the Public Procurement Regulations, particularly in providing training and studies, but not necessarily for fire management. Until the Department's capacity becomes adequate, the subcontracting process remains a viable option for securing experienced professionals for training in fire management.

\section{Training of fire management staff and community volunteers}

Awareness raising trainings are often organized with relevant non-government organizations (NGOs) and district security offices at local levels. Since 2007, Community Based Fire Management Initiatives in the Hills of Nepal (CBFiM) has conducted trainings in Baglung, Makwanpur, Parbat and Bhaktapur Districts. Specialised training is limited by there being only a few individuals in the country knowledgeable to provide services related to safety, equipment maintenance, incident command options and case administration. There have been no specific 
trainings by the Department; nor is there any standard training curriculum. At local level, training focusing only on awareness and preventive measures is part of the initiation of DFOs. Lack of training and skills among DoF staff is one of the key gaps in fire management.

\section{Stakeholder involvement}

Involvement of domestic stakeholders (e.g. community beneficiaries; management; staff; volunteers; general public) with the DoF's fire management programme is reflected by the government's high levels of participation, within its resource limitations, in local level activities such as: assessing needs; designing and implementation; monitoring. However, there is no mechanism in place within the Department to assess the effectiveness and impact of the aforementioned involvements.

\section{Infrastructure and technology}

The DoF has limited technology to handle fire management. International Centre for Integrated Mountain Development (ICIMOD) has introduced a GIS-based forest fire alert information system that provides alert information to the Department within 24 hours of an active fire. Such a time lag makes this an ineffective tool for response, unless the event is in an extremely remote area. Additionally, the service is only in English, thus limiting the number of people who can effectively respond to the information (ICIMOD, 2013). In other words, the present response system does not correlate with the monitoring and detection system.

\section{Collaboration and partnerships}

Few fire management related collaborations exist with other Ministries or Departments. However, DFOs do coordinate with their District Administration Offices, security offices (i.e. Police, Armed Police, Army, Park Rangers), local communities and NGOs to control any fire; and they have held many trainings, such as through the CBFiM. Occasionally, the Department has also had relationships with diverse international actors, namely:

$A C T$ : Australian Capital Territory Fire \& Rescue volunteers trained fire fighters in villages of Namche Bazaar and Lukla in the Solukhumbu District, in February 2015.

GFMC: Global Fire Monitoring Center, funded by GIZ, coordinates and facilitates the UNISDR Wildland Fire Advisory Group and the UNISDR Global Wildland Fire Network; conducts outreach on policy advice, networking and developing practical, community level models.

ICIMOD: International Centre for Integrated Mountain Development has supported development of and access to the satellite based fire alert system in some areas. 
JICA: Japan International Cooperation Agency, through a Memorandum of Understanding at the ministry level, provides some support, including fire fighting equipment (some of which has been found to have been deficient).

KFS: Korean Forestry Services invited the MoFSC Focal Person to an international conference.

MSFP: Multi Stakeholder Forestry Programme, funded by the United Kingdom, Switzerland and Finland and concluded in 2016, had provided funds for fire prevention activities in Kapilvastu, Dang and Dailekh Districts.

NFFMC: Nepal Forest Fire Management Chapter, a local NGO, provides a platform to provide policy dialogue at national level and provide capacity building at community level.

TRU: Thompson Rivers University and this present, holistic investigative collaboration.

USAID: Supported training in fire management and suppression with WWF in Rautahat, Bara, Chitwan, Kanchanpur, Kaski and Tanahun Districts, in 2013.

WWF: World Wildlife Fund's Hariyo Ban (Green Forest) programme supports various occasional initiatives.

While there have been sporadic training events, not even a quarter of the country's 75 Districts have been involved. Moreover, such project-based initiatives do not usually continue after the project is terminated due to unclear institutional mechanism and inadequate budget.

Since there is very limited modern equipment and knowledge available relating to fire management, the field forestry offices have to rely predominantly on local fire control practices such as swatting with branches. Moreover, at least one DFO has only two sets of fire fighting tools and, while theoretically these could be borrowed during a fire incident elsewhere, the sets are impractical to transport even to some hard to reach communities within the District, let alone to a neighbouring District.

\section{Sustainability of the Department's fire management efforts}

The DoF acknowledges and has the interest, knowledge and authority to integrate particular components for promoting sustainability in its efforts as time, knowledge, resources and higher level support permit. Knowledge, skills and willingness aside, effectiveness of the various components being integrated hinges on stability in personnel, funding for out-of-town meetings and activities as well as efficient follow-ups. Furthermore, the duration and intensity of this integrative modus operandi remains fluid. 


\section{Policy and legislation}

A comprehensive Forest Fire Management Strategy had been developed in 2010 (MoFSC, 2010) with recommendations relating to policy reforms, coordination among multi stakeholders as well as infrastructure development at local level. The document does not, however, suggest a correspondingly clear forest fire administrative system in the existing Department structure; moreover, the Strategy has not been followed up with an Implementation Plan. Consequently, forethoughtful responses to critical situations become displaced by ad hoc ones.

\section{Long-term planning}

Progressive, multisectoral national planning has demonstrated deliberate sequencing of forest related intentions--some specific to fires-- and the struggle with organizational restructuring. Such a background is useful in understanding the importance of keeping 'process', or how one designs implementation, as a priority, after some 70 years of planning. Reviewing Nepal's periodic plans for period of 1956 to 2019, as related to forestry, we can notice the following evidence of the government's incremental issues and considerations related to fire management.

The Third Plan (GoN National 1965-1970) had the first mention of fires when damage was acknowledged as destructive to land management and livelihoods. The Sixth Plan (GoN National 1980-1985) stated that 'additional projects will be included in the plan ...if negotiation with aiding countries are concluded satisfactorily'. Such planning modality assumes if a donor cannot be found, plan components might be excluded or postponed; if a donor is supportive, then usually the component would need to confirm to the donor's preferred approach and programme, frequently along with donor-specified accounting over and above the regular accounting. The Eleventh Plan (GoN National 2007) recognized that ' $[i] n$ the context of full devolution, the central government will limit its functions to policy formulation, setting norms, quality control, human resource development, technical support, capacity enhancement, central level studies and research, monitoring and evaluation needed to be done by the central level and construction of big infrastructure development projects and the rest will be devolved to local bodies'. This was necessitated by acknowledgement that decentralization, for the purpose of better prevention, mitigation and suppression services for fires, had not worked in enough locations. As amply attested to by the government itself, reasons included inadequate preparation and support of the field personnel as well as the ambiguity and indecision in the division of roles and responsibilities between the centre and the periphery.

The Twelfth Plan (GoN National 2010) noted that persistent under-performance at the centre had exhibited reluctance of the established administration to part with power. There had been lack of capability among personnel at all levels to shoulder higher responsibilities, viz: 'Although programs were taken up as goals to implement with priority, their effective implementation has hardly been materialized' as a result of 'lack of technical and skilled 
manpower in implementing plans, ...lack of institutional development of local bodies, lack of implementation of Local Self-Governance Act and Regulations, lack of amending laws and regulations colliding with the provisions for devolution, lack of financial discipline at the local bodies, duplication in works of governmental and nongovernmental organizations'. The most recent Fourteenth Plan (GoN National 2016) belatedly identified forest fire as a challenge within the forest and soil conservation sector, requiring operational strategies for organizational structure, preparedness, fire lines' management, rain water collection, and an increase in people's participation. Resources and management capacity are to be enhanced for forest fire control and management. Expected outcomes from proper implementation of this Plan should be improved fire control, which in turn will help mitigate impacts of climate change and natural disasters.

Overall, there have been repeated efforts to strengthen decentralization through the design and promotion of local bodies with their respectively devolved authority and responsibilities. However, as the Constitution does not provide an elaboration for the organizational scheme of local government decentralization, parliament and the respective Ministries needed to- but have not yet been able to- develop these mechanisms to apply contextually to the different subcentral administrative divisions. While the objectives have been laudable, the periodic planby-plan introduction of new committees and programmes has not served the greater purpose. Sometimes, it may be more efficacious to revise and improve existing local or traditional modalities than to evolve new ones ab initio.

The task, now, is to determine which important services are better done at the centre; how to ensure understanding of and support for these services by the field; how to provide the same by the centre to the field; what mechanisms to utilise in the sharing of the central learning with the field; how to devise equitable and rational sharing of responsibilities with the field; and how to cooperatively engage the field in its application of centrally developed learning deemed essential and which, in some cases, may require local adaptation. This must be exhaustively thought through, for acceptance of too many different systems and responsibilities at any one level may lead to unanticipated complexity; and sustained complexity could overpower performance, leading to yet another governance restructuring exercise that could have been avoided.

\section{Decentralization, as one option}

Decentralization is typical in organizations that have complex and rapidly changing contextual conditions. The Twelfth Plan (GoN Nepal 2010) states: 'Objectives, strategies and working policies of forests sector have been designed with the view of contributing in poverty alleviation of local communities by improving their livelihood through promotion of ecosystem services and mitigation and adaptation measures of negative impacts of climate change by sustainable, 
participatory and decentralized management of forests, plant resources, watersheds, protected area, and bio-diversity resources'. The Plan continues: 'Forests will be protected from fire through participatory approach by applying prohibitive and controlling measures' (ibid).

Presumptively, the purpose of decentralization is to increase responsiveness to fires by allowing Field Offices and communities more discretion to make decisions affecting their areas of responsibility. In practice, unfortunately, paucity of resources and inadequately trained and equipped responders have weakened the necessary prevention, mitigation and suppression activities.

Decentralization and increased delegation of authority would demand balance between the need for control and the desire to provide responsive, efficient and effective service closer to the locus of fire or potential fire. This would require much more systematic management and development of Field staff, with a greater emphasis on individual accountability. The Field (DFOs; CFUGs) must thereupon be equipped to accept new responsibilities with commensurate authority. Increasing population shifts combined with climate change are gradually increasing frequency, complexity and risk and therefore demand an improved, contextual management.

\section{Centralisation, as another option}

So long as objectives and priorities by the government to provide optimal service to its citizens are kept in mind, centralisation has major potential advantages; but if poorly thought out and implemented, it can inhibit or limit rurally relevant local initiatives, while likewise denying the field economies of scale or coordinated strategies so crucial for efficient responses to fires in one or multiple jurisdictions. But excessive bias toward centralization and control can also mean that the progressive accumulation of incremental decisions can eventually lead to an overly centralized system.

We find following seven aspects that would benefit from central focus:

Information technology: a contemporaneous example applies to the use of IT to facilitate communication, service delivery and interaction with citizens, staff, domestic stakeholders or foreign partners.

Research: to support and rationalize decisions for iterative enhancement of fire management by analysis, distribution and extrapolation of applicable elements.

Policies and allied laws: development of national regulations and rules with attention to allowance for reasoned, contextual field application.

Statistics and analysis: the wherewithal to discern, organize and act upon considerable data relevant to Nepal and available through national and various global organizations is becoming more important with global climatic changes. 
Training development and coordination: piecemeal, uncoordinated upgrading and updating activities can undermine the integrity of an otherwise well-intentioned system. It would be more effective to determine priorities and harmonize any international assistance to areas of greatest need in combination with assurance for the presence and involvement of various Districts.

Communication and documentation procedures: standardization of regular and irregular communication channels and systems is necessary, along with report protocols that ensure brevity, clarity and quick readability accessible to all.

Procurement, maintenance and distribution: ensuring availability in times of need, design of appropriate tools with interserviceability and local repairability, and domestic employment rather than dependence on donations, require serious effort.

Lastly, Bloch and Bugge (2013) claim that 'There is also evidence from a survey of Nordic countries to suggest that central government departments or institutions tend to have scope for more innovative or novel reforms in comparison with non-central departments or institutions, which tend to have more incremental innovations.'

\section{Deciding factors for the two options}

Different choices and methods of wildfire management are- or should be- in part a reflection on Nepal's topographical and ecological contexts and of the different forms of natural resource management practiced. For decentralized government to succeed, the centre must enable it; thus, work modalities must give attention to human resource needs (Does the field have the required staff to deliver the decentralized services?); budget transfer mechanisms (Are the field offices provided the funds required to carry out their responsibilities? Is there any discretionary decision-making allowed?); integration of field office modalities with attendant national systems (Are the field regulations in line with national policies, directives and priorities? Is there any rational flexibility for patently different contexts?); and integrative administration (Are central and field level planning jointly done? Are the time parameters for planning coordinated?).

These dichotomous reasons for centralised or decentralized systems lead to basic questions needing affirmation by the ministry for a confident decision (Table 1): 
Table 1: Decision-making aide-memoire

\begin{tabular}{|c|c|}
\hline Major issue & Supplementary issues \\
\hline $\begin{array}{l}\text { Is the centralisation } \\
\text { mandated? }\end{array}$ & $\begin{array}{l}\text { - Do laws, policies or regulations require it? If so, specify. } \\
\text { - Would a new Unit operate under a predictable legal framework? } \\
\text { If so, specify. } \\
\text { - Do key stakeholders demand it? If so, compile a list of such } \\
\text { stakeholders. }\end{array}$ \\
\hline $\begin{array}{l}\text { Would centralisation } \\
\text { add significant benefitto } \\
\text { the Ministry's services } \\
\text { and operations? }\end{array}$ & $\begin{array}{l}\text { - Can the Ministry and its Departments achieve their goals using } \\
\text { their current processes? If not, provide reasons. } \\
\text { - Would focusing discrete responsibilities at the centre augment } \\
\text { effectiveness and efficiency in the overall bureaucracy: } \\
\text { administration, coordination, management, procurement, field } \\
\text { response, community engagement, communication, resourcing } \\
\text { etc.? If so, how? } \\
\text { - Would it improve service quality and speed for preparedness } \\
\text { and in times of crisis? If so, how? } \\
\text { - Would staff and community motivation be increased? If so, } \\
\text { how? } \\
\text { - Would costs justify the reform? If so, provide details. }\end{array}$ \\
\hline $\begin{array}{l}\text { If 'Yes' to the above, } \\
\text { then centralisation } \\
\text { seems correct; but.... }\end{array}$ & $\begin{array}{l}\text { - Do the Ministry and Department currently have the will, } \\
\text { capacity and capability to implement the process of forming a } \\
\text { new Unit? } \\
\text { - Do realistic options exist for securing the resources to initiate } \\
\text { and operate this new Unit without reducing allocations to the } \\
\text { periphery or other essential programmes? } \\
\text { - Could and would the new Unit be provided with sufficient } \\
\text { flexibility to take independent decisions in heterogenous } \\
\text { contexts or during a crisis? } \\
\text { - Would there be a process for measuring success of the new } \\
\text { Unit? If no, you must not proceed. If yes, provide monitoring } \\
\text { and evaluative indicators and process. }\end{array}$ \\
\hline
\end{tabular}

Few legislative acts, regulations and policies related to the forestry sector address the needs of fire control and management specifically or adequately. The Forest Fire Management Strategy is still awaiting a complementary, practical implementation plan. This weakness is 
compounded by a combination of intersectoral factors - politico-administrative, environmental, and socio-cultural - that are gradually having a deleterious effect on both the potential severity of incidents and the efficacy of future responses (Table 2). Steps taken now shall influence the environment in the future.

Our discussions and observations highlight the insufficient central level priority given to improving fire management. Perhaps finances are behind a reticence to more fully engage: if so, a budgeting exercise must be undertaken by the government to determine realistic allocations for establishment of a new unit. While internal funding from government would be preferred, a strong case could be made to certain donors for collaborating in this initiative for a predetermined start-up period.

To effectively manage and administer a comprehensive fire management strategy, it is advisable to set up a dedicated unit within the Ministry, complemented by similar units in each of the Departments of Forests as well as National Parks and Wildlife Conservation to oversee fire management improvement. While presently a designated Focal Person seems to be a temporary designation for staff with other primary responsibilities, a newly dedicated unit must be headed full time by a person experienced in various facets of fire, administrative skills, established global connections within the sector, as well as aptitude for integrating the roles and responsibilities of allied institutions. Job descriptions for the unit head as well as three to five other staff must then be created and updated, as requirements oblige. Such a new unit would set national policy, while leaving selective flexibility, to yet to be determined levels of responsibility in interpretation and implementation., to the newly established jurisdictions of municipalities (Nagar Palikas), rural municipalities (Gaun Palikas), District Coordination Committees and Provinces.

Together with empowerment of community people --an already common practice in Nepal-- the inception and measured development of this new unit must incorporate technical upgrading and management skills for its employees; only then could staff credibly contribute to a well-designed operational plan and conduct or coordinate trainings in the periphery with sub-provincial offices, many of whom lack fire control knowledge and technology. Modern operational plans must include details on fire service safety, safety standards, inter-jurisdictional procedures and general administration.

It is improbable to respond to fire emergencies without adequate numbers of well trained staff using appropriate fire control and management equipment, including personal protective gear. Reliance on donor-supplied materials and equipment entails risks similar to those found in other sectors (Somlai, 1994) ${ }^{1}$. Most tools and equipment, including portable water bags, which have been thus far donated to various communities, National Parks and District Forestry

\footnotetext{
${ }^{1}$ It was found that 45 hospitals in Nepal were using donated X-Ray machines from 20 countries, limiting compatibility of spare parts or any chance of reliable repairs. Similar inconveniences have happened in agricultural, microhydel and fire suppression apparati.
} 
Offices could be manufactured in Nepal at reasonable cost and under direct quality assurance; furthermore, local production would facilitate the replacement or interchangeability of spare parts for repairs and provide much needed employment.

Nepal has deservedly earned worldwide reputation for its promotion of community participation in forest care, including fire prevention, mitigation and control; but while the 13,528 CFUGs (FECOFUN, 2017) ${ }^{2}$ control forest fires within their own forests, it is done without standard plans. Moreover, as communities change in their composition, as some grow from internal migrants who have little interest in the forest while others contract from outmigration and thus have fewer people ready to respond to emergencies, community plans need to be constantly updated and effective responses practiced. In this respect, and considering that a complex configuration of local cultural, social, economic, political and environmental conditions determines the definition and design of collaborative programmes (Kamminga, 2001; Goldammer et al, 2002), it may be useful for the Department of Forests to collaborate with universities and involve sociologists and anthropologists to further understand unique characteristics of each community. Community members, regardless of their respective longevity within the community, must have some obligation and preparedness, to contribute to fire suppression.

A new tradition encompassing a holistic consultative process must be initiated for enhanced effectiveness of the Department through increased and more meaningful participation of stakeholders. Such a consultative process, while providing complementary technical and policy initiatives from the top down central level, would engage communities and NGOs from the bottom up in seeking pragmatic, locally appropriate interpretation and field application. Leadership for such an increasingly important endeavour must come from the new unit.

${ }^{2}$ Number of CFUGs vary from 10,000 to 16,000 , according to different sources. 
Table 2: Inter-sectoral influences on fire management \& related recommendations ${ }^{3}$

\begin{tabular}{|c|c|c|}
\hline Environmental & Politico-administrative & Socio-cultural \\
\hline $\begin{array}{l}\text { - Climate change (UNDP, } \\
\text { 2013; ICEM et al. 2014) } \\
\text { - Extreme physiography } \\
\text { causing longer recovery of } \\
\text { degraded forests (ICEM } \\
\text { ibid.) } \\
\text { - Increased surface runoff \& } \\
\text { dry periods (Government o } \\
\text { Sikkim 2015) } \\
\text { - Springs becoming seasonal } \\
\text { (Government of Sikkim } \\
\text { ibid.) } \\
\text { - Soils drier in summer- } \\
\text { >less evaporation->less } \\
\text { recycled moisture->less rain } \\
\text { (Government of Sikkim } \\
\text { ibid.) } \\
\text { - Changing alpine ecosystems } \\
\text { (Government of Sikkim } \\
\text { ibid.) Ascending fires(Government } \\
\text { of Sikkim ibid.) } \\
\text { - Forest encroachment } \\
\text { (Khanel, K.R. et al 2007) } \\
\text { - Common fire causes: natural } \\
\text { \& anthropogenic } \\
\text { - Increased probability of } \\
\text { recurrence, worsening } \\
\text { severity \& intensity (ICEM } \\
\text { ibid.) }\end{array}$ & $\begin{array}{l}\text { - No coordinating unit; } \\
\text { only Focal Person } \\
\text { with inadequate } \\
\text { time because of } \\
\text { other prioritized } \\
\text { responsibilities } \\
\text { - Absence of } \\
\text { Implementation Plan } \\
\text { for 10-Year Fire } \\
\text { Management Strategy } \\
\text { (MoFSC, 2010) } \\
\text { - No clear link with } \\
\text { existing, generic } \\
\text { disaster response } \\
\text { modalities at any level } \\
\text { - No legal or financial } \\
\text { base confirmed for } \\
\text { an essential national } \\
\text { coordinating unit } \\
\text { - S u b o p t i m a } 1 \\
\text { o r g a n i z a t i o n a } 1 \\
\text { efficiency }\end{array}$ & $\begin{array}{l}\text { - } \begin{array}{l}\text { Population increase/ } \\
\text { density }\end{array} \\
\text { - Unmanaged influx not } \\
\text { directly forest dependent } \\
\text { (commuters; economic } \\
\text { migrants) (MoFSC, } \\
\text { 2015d) } \\
\text { Outmigration from rural } \\
\text { communities resulting } \\
\text { in fewer hands for fire } \\
\text { response in rural areas } \\
\text { Diverse coexisting ethnic } \\
\text { migrant groups may differ } \\
\text { in traditional fire control } \\
\text { (Colfer, 1999a, 1999b) } \\
\text { More people affected in or } \\
\text { near urban areas; but fewer } \\
\text { capable of appropriate } \\
\text { response or willing to help }\end{array}$ \\
\hline $\begin{array}{l}\text { A. Resulting from the above } 3 \\
\text { contexts are: }\end{array}$ & $\begin{array}{l}\text { - } \quad \text { Inevitable recurrence o } \\
\text { - } \quad \text { Porsening severity of } \\
\text { and handling fires }\end{array}$ & $\begin{array}{l}\text { f fires } \\
\text { fires } \\
\text { hed capability in responding to }\end{array}$ \\
\hline
\end{tabular}

\footnotetext{
${ }^{3}$ Unattributed notes in the three intersectoral columns were confirmed by personal discussions with 140 government and NGO professionals and functionaries at all levels.
} 
Table 2: continue

B. This requires set-up of a dedicated Unit at the central level institution looking after forest sector:
- Focus on forest and wildfire management in a coordinated way with all relevant departments, institutions, communities and organizations

- Turn separate initiatives into a balanced, integrated programme change

- Develop fire management concepts, improve capacities at all levels and initiate sustained awareness raising campaigns

C. Suggested focused responsibilities of the Fire Management Unit should include, inter alia and in a progressive manner:

- Coordinate the National Implementation Plan for the Forest Fire Management Strategy 2010

- Develop procedural guidelines for operative regulations of Forest Policy 2015

- Develop proposal for appropriate administrative and operational set up of decentralized coordinating offices in the newly delineated Provinces and other lower jurisdictions

- Create focus and develop conditions for improving systems and capacities in fire analysis, preparation, response and documentation

- Promote broad-based stakeholder input to maximize innovation and knowledge sharing; establish and maintain actual and potential collaborative network

- Administer data collection, recording, analysis, dissemination

- Create or refine central level policies for provincial, district and community level implementation

- Research and analyse community and tradition-related practices for fire prevention and control; methods for sharing and transporting expertise, equipment and other assets among different fire locations; building of water storage tanks in critical areas; fire outbreaks, suppression and fire ecology; production and procurement of locally produced rural fire control tools, equipment and materials, along with allied inventory control

- Design standard training curriculum and training schedule

- Enhance communication procedures for all jurisdictional levels

- Compile criteria and job descriptions for other required staff

- Establish budgets and timelines for the above 


\section{Conclusion}

As climate change has become an undeniable element in the severity of fires and resultant complications, inability to improve fire management is expected to intensify the adverse impacts. Incidents of forest fires may easily counteract the nation's endeavour to protect and expand forest area; since February this year, over 500 wildfire-related events were reported across the country, causing a total of 350,000 hectares of forest to be burnt down (Indo-Asian, 2016). Thus it seems to be a serious waste of resources to carry on irregular interventions and to continue to receive unheeded reports clearly defining the requirement for appropriate governance changes such as 'develop(ing) a national institutionalized fire training program across all levels of Government' (McHugh, 2013). Interventions by various agencies have sporadically brought some equipment, materials and skills training to selected communities. Recognizing the difficult physiographic reality, funding shortage and the ability of only certain communities to respond effectively to any fire incidents, it is necessary and timely to have, within the government, one single unit with special knowledge and skills empowered to focus at central and decentralized levels in preventing, mitigating and suppressing forest and wildfires that endanger communities. It had been further stated years back that 'Systematic arrangements for prevention, control, and management of forest fires can be instituted in Nepal only when scientific forest management is implemented within the Department of Forests for state and community forests' (Bajracharya, 2002; MoFSC, 2015a,b,c). Recent cautionary research indicates, however, 'that technical forest management plans have been elaborated haphazardly and that local communities base their management on other sources of knowledge. Further, community-level managers appear well-informed about forest condition and their practices contribute to sustainable forest development' (Rutt et al, 2015). Accordingly, the government must maintain a balance of technical and traditional knowledge in dealing with fire issues.

Despite costly resources (in terms of funds, personnel, time) to develop the Plans and apply the guidelines and directives arising from the approved Plans, sustained desired results have eluded the citizenry. This, therefore, emphasizes that the process of how plans are developed, ratified and implemented must be improved.

One aspect, concerning any donor involvement, is that the government ought to internally clarify the priorities and components that could be open to support from outside donors; then the government must justify the priority need to potential donors, indicate how the component need be executed and managed, and invite assistance under those stated conditions. Thus the MoFSC must remain in charge, diplomatically reject those who cannot contribute without needing to be in charge; and thank any who are amenable to working collaboratively on Nepal's terms.

In a debriefing meeting with our team, the then Minister acknowledged the seriousness of this gap, apprised us of upcoming internal consultations on restructuring within newly 
created administrative boundaries, and committed to ensuring the establishment of a dedicated unit to coordinate fire management activities with more organizational responsiveness.

It is essential to move forward with a dedicated unit now, because without any improvement in addressing the natural (climate change) and anthropogenic causes (population shifts, deforestation, carelessness) and response effectiveness, consequences will inevitably multiply and cannot be resolved in the field. Continuing irresolution because of lack of time for reflection and planning, awaiting sub-central administrative level resolutions and/or inability to access adequate financial resources will simply increase the need for intervention and development of new efforts and policies by future caretakers.

\section{References}

Bajracharya, K. M. (2002). Forest fire situation in Nepal. International Forest Fire News, 26, 84-86.

Bloch, C., \& Bugge, M. M. (2013). Public sector innovation-From theory to measurement. Structural Change and Economic Dynamics, 27, 133-145.

Colfer, CJP. (1999a). Kenyah perspective on Kalimantan's fires - an interim document. Bogor, Indonesia: Centre for International Forestry Research.

. (1999b). Ten propositions to explain Kalimantan's fires - a view from the field. Bogor, Indonesia: Centre for International Forestry Research.

Food and Agriculture Organization (FAO). (1999). Report on public policies affecting forest fires. Rome: FAO.

Federation of Community Forestry Users Nepal(FECOFUN). (2017). Federation of Community Forestry Users, Nepal. Retrieved February 15, 2017 from http://www.fecofun.org.np/ members.php.

Khanel, K. R., Shrestha, K. R., Acharya, K. P., Pachhai, I. B., Sharma, S. P. (2007). Development of a national strategy for wildland fire management in Nepal. Kathmandu. Global Fire Monitoring Center.

Goldammer, J. G., Frost, P. G., Jurvélius, M., Kamminga, E. M., Kruger, T., Moody, S. I., \& Pogeyed, M. (2002). Community participation in integrated forest fire management: experiences from Africa, Asia and Europe. International Conference on Community Involvement in Fire Management Vol 25. Communities in Flames (pp 33-52). Bangkok:

FAO Regional Office for Asia and the Pacific.

Government of Nepal (GoN). (1985). Forest act 1985 (Ban Ain 2041). Kathmandu: Nepal Law Commission.

. (1992). Civil service act 1992 (Nijaamati Sewaa Ain 2049). Kathmandu: Nepal

Law Commission.

. (1993). Forest act 1993 (Ban Ain 2049). Kathmandu: Nepal Law Commission. . (2006). Public procurement act 2006 (Saarbajanik Kharid Ain 2063). Kathmandu. 
Nepal Law Commission.

. (2007). Public procurement regulations 2007 (Saarbajanik Kharid Niyamaawali

2064). Kathmandu: Public Procurement Monitoring Office.

National Planning Commission (NPC). (1965). Third plan (1965-1970). Kathmandu: NPC.

. (1980). Sixth plan 1980-1985. Kathmandu: NPC.

. (2007). Eleventh plan 2007/8-2009/10. Kathmandu: NPC.

. (2010). Twelfth plan 2010/11-2012/13. Kathmandu: NPC.

. (2016). Fourteenth plan 2016/17-2018/19. Kathmandu: NPC.

International Centre for Environment Management (ICEM), International Institute for Environment and Development (IIED), School of Environment Science and Management (SchEMS). (2014). Strategic environmental and social assessment (SESA) of the REDD+ strategy. Kathmandu: Ministry of Forests and Soil Conservation.

International Centre for Integrated Mountain Development (ICIMOD). (2013). ICIMOD and MoFSC launch near real-time forest fire alert system. Kathmandu: ICIMOD. Retrieved March 11, 2016 from www.icimod.org/?q=10092.

Indo-Asian News Service (IANS). (2016, May 15). Nepal's forest cover increases by over five per cent. Delhi. Times of India. Retrieved August 22, 2016 from http://timesofindia. indiatimes.com/world/south-asia/Nepals-forest-cover-increases-by-over-five-percent/articleshow/52279804.cms

Kamminga, E. (2001). Impact of the integrated forest fire management program on rural livelihoods in East Caprivi Region, Namibia. International Forest Fire News, (25), 39-57.

Khadka, N.S. (2016, May 13). Fanned up flames. The Kathmandu Post. Retrieved July 3, 2016 from http://epaper.ekantipur.com/the-kathmandu-post/2016-05-13/7.

Magrath, W. B., Shrestha, A., Subedi, B., Dulal, H. B., \& Baumback, R. (2013). Nepal forest sector survey: Policy priorities and recommendations. Washington, DC: Program on Forests (PROFOR), The World Bank.

McHugh, C. W. (2013). Observations and recommendations on fire management in NepalFinal Report. Missoula, MT: USDA Forest Service, Rocky Mountain Research Station Fire, Fuel, and Smoke Science Program, Fire Sciences Laboratory.

Ministry of Forest and Soil Conservation (MoFSC). (2010). Forest fire management strategy 2010 (Dadhelo Byawasthaapan Rananiti 2067). Kathmandu: MoFSC.

. (2015a). Scientific forest management guidelines 2015 (Baaigyanik Ban Byawasthaapan Kaaryabidhi 2071). Kathmandu: MoFSC.

. (2015b). Forestry sector strategy 2015. Kathmandu: MoFSC.

. (2015c). State of Nepal's forests 2015 (Raashtriya Banshrot Sarwekshan Nepal

2073). Kathmandu: Department of Forest Research and Survey. . (2015d). Asia Forestry Outlook Study 2020: Country Report Nepal. Kathmandu: 
MoFSC.

Onlinekhabar. (2016, March 13). Wildfire spreading for three days in Udayapur district, hundreds of people under threat. Kathmandu. Retrieved May 14, 2016 from http:// english.onlinekhabar.com/2016/03/13/372341.html

Rutt, R. L., Chhetri, B. B. K., Pokharel, R., Rayamajhi, S., Tiwari, K., \& Treue, T. (2015). The scientific framing of forestry decentralization in Nepal. Forest Policy and Economics, (60), 50-61.

Sharma, S. P. (1996). Forest fire in Nepal. International Forest Fire News, (15), 36-39.

Government of Sikkim. (2015). Action plan on climate change. Gangtok: Government of Sikkim.

Somlai, I.G. (1994). Report of the Member-Secretary, Ministry of Health Committee on Preventative Maintenance and Repair of District Medical Equipment in Nepal, 19931994. Kathmandu: Ministry of Health.

United Nation Development Programme (UNDP). (2013). Nepal climate change support programme: Building climate resilience in Nepal. Kathmandu: UNDP.

United Nations Office for Disaster Risk Reduction (UNISDR). (2007). Round table for the development of a national strategy for wildland fire management in Nepal. Kathmandu: UNISDR. Retrieved April 22, 2016 from http://www.fire.uni-freiburg. de/GlobalNetworks/South_Asia/Meetings_activities/Nepal-Fire-Round-Table-Report. pdf

United States Forest Service (USFS). (2014). Strategic review and recommendations - forest fire risk management and the future of fire management in Nepal. Kathmandu: USFS. 
Annex 1: Organigram of the Department of Forests, Nepal

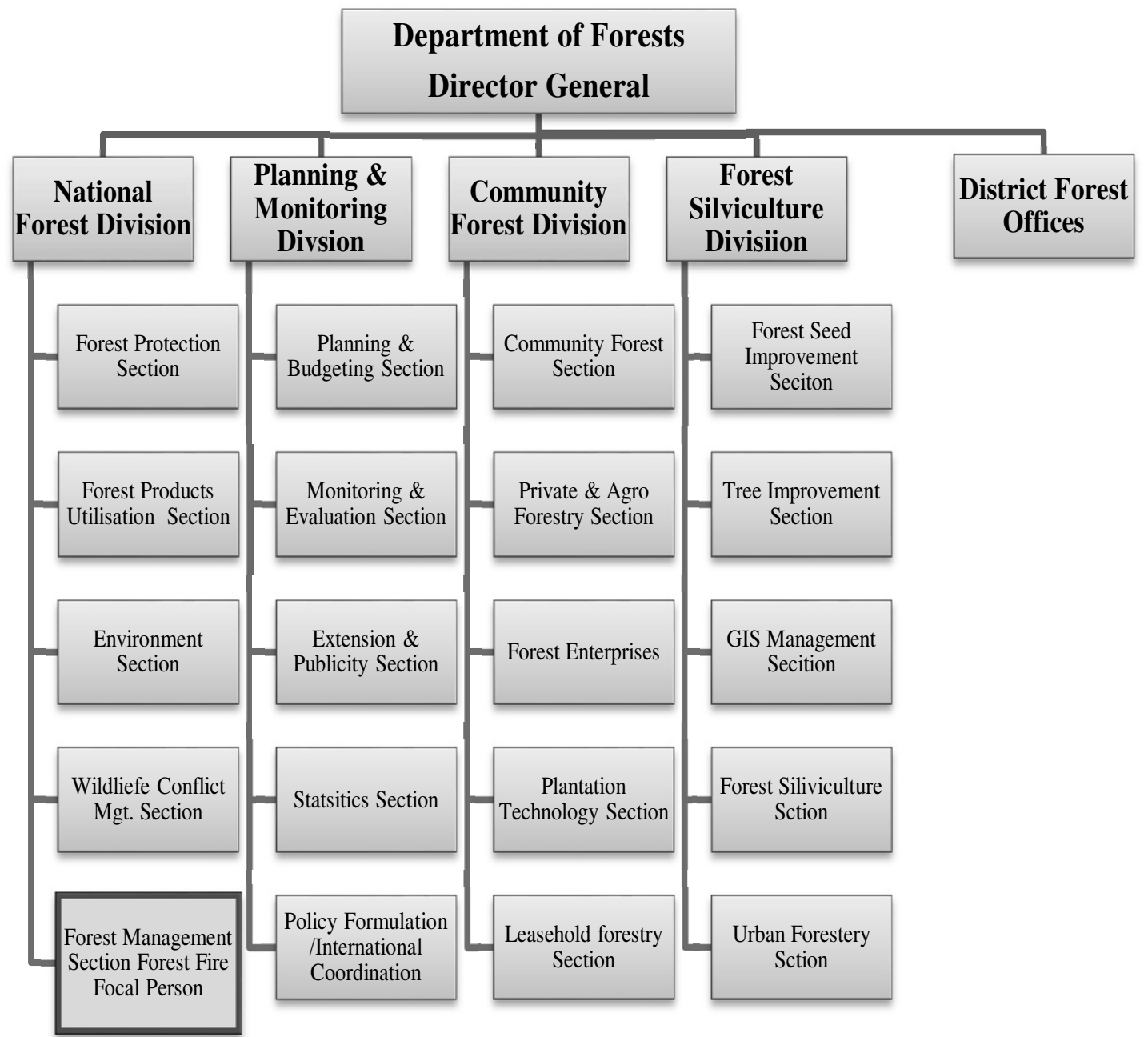

